\title{
"UNDRAPE!": ON NAKED READERS IN MELVILLE AND WHITMAN
}

\author{
Alan Trachtenberg
}

In August 1885, THE ACADEMY, an English journal of letters, published a poem dedicated to Walt Whitman, titled "Socrates in Camden, With a Look Round." The author-Scottish poet, critic, and Owenite socialist Robert Buchanan - had visited Whitman earlier that year, and in some two hundred and fifty rhymed tetrameters hailed the poet as "fearless, self-contained, and bold," especially in face of the contempt, the "social poison," served upon him by the Boston coterie of polite writers. Buchanan portrayed Whitman as a rough-and-ready Socrates who mixed with crowds on street corners, tipped his cap to prostitutes, and who, his voice like a trumpet, "proclaimed / The naked Adam unashamed." For these offenses he was roundly rebuked by the fastidious Elders and now "shines solitary and apart," a "sun-like music-maker," while the fashionable writers are two "man-milliners and drapers," sartorial artists named Howells and James. "The busy pair," Buchanan sneers, "How well they patter, / Disposing of their slender matter. / The girls adore instead of loathing / These laureates of underclothing."

Buchanan then turns his playfully sartorial trope to another brave writer maligned by the prudishness of American critics, a "sea-compelling man, / Before whose wand Leviathan / Rose hoary white upon the Deep, / With awful sounds that stirred its sleep." Herman Melville, he writes,

Sits all forgotten or ignored,

While haberdashers are adored.

He, ignorant of the drapers' trade,

Indifferent to the art of dress,

Pictured the glorious South-sea maid

Almost in mother nakedness-

Without a hat, or boot, or stocking,

A want of dress to most so shocking.

In a note, Buchanan adds that he "sought everywhere for this Triton, who is still living somewhere in New York. No one seemed to know anything of the one great imaginative writer fit to stand shoulder to shoulder with Whitman on that continent." 
Considering how rarely Melville and Whitman crop up together in American criticism, it's notable that in yet another essay in praise of Whitman, the Scottish poet and essayist James Thomson also remarked, in 1874, that the only "other living author who approaches him in his sympathy with all ordinary life and vulgar occupations" is Herman Melville. ${ }^{2}$ Thomas is best known for despairing passages in City of the Dreadful Night, a poem about which the aging Melville wrote favorably to a British correspondent in 1888 that "its gloom is its sublimity."3

Melville received a copy of the Buchanan poem from a young English admirer, and in September, several months before his retirement after twenty years of obscure service in the New York Custom House, he replied: "For more than one reason, this Piece could not but give me pleasure. Aside from its poetic quality, there is implied in it the fact, that the writer has intuitively penetrated beneath the surface of certain matters here" (Letters, 278). What he meant by "certain matters here" is left to our surmise, but we hear another tantalizing allusion to Whitman in a letter Edmund Clarence Stedman, friend to both writers, wrote to Melville more than two years later in which he recalled that Melville had recently "said so much of Whitman." These two, faint traces of a response to Whitman may hardly suffice as a belated shock of recognition, but they do suggest interesting possibilities. Could it be that in Buchanan's poem Melville found a late and unexpected literary confederate?

One plausible confederacy may lie in the Carlylean "art of dress" Buchanan makes so much of. Both writers had on occasion crossed a line by picturing nudity as nudity without shame or apology. Whitman opens his first poem in 1855 virtually in the buff: "I will go to the bank by the wood and become undisguised and naked, / I am mad for it to be in contact with me." ${ }^{5} \mathrm{He}$ invites the reader to join him: "Undrape [...] I see through the broadcloth and gingham whether or no" ( $L G 1855$, 17). This is apart from unspeakable displays of the body and the naming of body parts as in "I Sing the Body Electric" and "Spontaneous Me." Several years before, in Typee (1846), Melville had shown the way in a sense by shamelessly having his hero, clearly the author himself, cavort with flimsily clad maidens - though the dusky color of their skin may have seemed cover enough to prudish readers. Melville may have also understood decorum as the figurative apparel donned by the author in his self-presentation, indeed as the entire fabric of words that is the literary work itself. Decorum in this light would refer to expectations that mediate the contact between writer and reader, assumptions about literary work as such.

Melville may have recognized a common situation with Whitman in yet another regard as well. Nothing could have been clearer than Whitman's break with traditional ideas of what poems should look like, not 
only on the page, but in the mind and imagination. "No one will get at my verses who insists upon viewing them as a literary performance," he said and went on to explain that the "main contrast" between his verses and "establish'd poems" is "the quite changed attitude of the ego, the one chanting or talking, towards himself and towards his fellow-humanity." While the attitude of Melville's ego or persona usually strikes a more familiar bearing, that of a story-teller telling true stories, difficulties with readers arose as his intentions grew more complex, dark, and challenging. ${ }^{7}$ By the time of Moby-Dick, metaphysical questions about fiction and truth increasingly complicated his narratives and eventually, after The Confidence-Man, led to an impasse and his famous spell of silence. The elaborate masquerading of his final novel is reason enough to suspect that Melville would perceive deeper implications in "art of dress" than Buchanan himself registered. While Whitman seems to discard dress and fabrication altogether, and Melville comes more and more to insist on it, both writers clearly defied convention by asking readers to divest themselves of habitual expectations regarding written works. The risk was enormous. Conventions of genre, of style and tone and structure, assure writers of readers. Confidence comes with mutual acceptance of an art of dress, mutual willingness to believe in a fabrication, to take pleasure from predictably constructed artifice. Don't expect the usual, Whitman warns at the outset. Melville mocks readers who naively expect the usual. Both authors issue warnings, even if couched in cryptic terms. "Have you felt so proud to get at the meaning of poems?," asks Whitman; "Stop this day and night with me and you shall possess the origin of all poems." "How unreal all this is," comments Melville's narrator in The Confidence-Man. And how strange that readers should demand "severe fidelity to real life" of a fiction that by its very fictitiousness can provide "more reality, than real life itself can show." 9

Both writers sought to encourage, even coerce, readers to reflect on what reading means, what it entails as an undertaking in the first place. Whitman's case is a figurative undressing in order to reach the base of all guises and costumes, the naked form, the body from which the "you" and the "I" take their identity, their "nighest name" ( $L G$, 164). The process of undraping aims to transform spectator into participant in the discovery of nakedness as the existential basis of identity. Melville does not so much alter the posture of spectator as challenge unexamined certainties such as the demand for "veracity," the entire "doctrine of assumptions" (in the resonant phrase from "Bartleby the Scrivener") by which readers attend to fiction and perhaps confuse fictions and realities. ${ }^{10}$

What we are after, then, is the image of reading each writer projected, an image that serves as a provisional guise or set of clothing for 
the reader. The full content of the image is the actual work the reader performs and in this sense is coextensive with the text itself. The basic terms of Melville's conception of the problem are prefigured in his first appearance as fictionist, in the preface to Typee. Prefaces are a conventional mode whereby writers can address the public in their own person as author rather than fictive person as narrator or character. In his inaugural appearance as author, Melville's aim is to persuade the reader of the factualness of the narrative to follow, to plea for its veracity. He already anticipates a difficulty: some elements in the story may strike the reader as "incomprehensible." 11 To prepare the reader for this, he is at pains to establish a context of credibility. He confesses to having been a sailor, "tossing about on the wide ocean," and sailors "are the only class of men who now-a-days see anything like stirring adventure; and many things which to fire-side people appear strange and romantic, to them seem as common-place as a jacket out at elbows" (vii). These figures of speech are homely, and the plea for indulgence is based on an innocent logical statement of relativism: fire-side people will readily admit to reading books for the sake of vicarious adventure. These very figures, sailor vs. homebody and the opposite perspectives they represent, will undergo remarkable deepening and complication in the next few years of Melville's career, a process already under way in the final paragraph of the preface:

There are some things related in the narrative which will be sure to appear strange, or perhaps entirely incomprehensible, to the reader; but they cannot appear more so to him than they did to the author at the time. He has stated such matters just as they occurred, and leaves every one to form his own opinion concerning them; trusting that his anxious desire to speak the unvarnished truth will gain him the confidence of his readers. (ix)

Words like "unvarnished truth" and "confidence" have a portentous ring here, hinting at Melville's emerging concern (if not obsession) with the intelligibility of any account of experience. But his explicit purpose now is to forewarn his readers that the incomprehensible may appear even within this truthful account of the narrator's experiences, harmlessly spicing them with romance. What the preface designs to exact from the reader is willingness to accept a shift in point of view from that of the fire-side person to that of the sailor, hence allowing the strange and the romantic, even the incomprehensible, a provisional commonplace status. If anything in the narrative is obscure, the author cannot be blamed through any perversity or deceit; that's how things were. ${ }^{12}$

At the end of Chapter One, Melville gives the reader a mild example of the indulgent shifts of perspective the narrative as a whole will require. The narrator recounts a "somewhat amusing incident" in which 
an "intrepid missionary" introduces his young wife among the natives (5). They find her at first a "prodigy," "some new divinity," as she no doubt regards herself as appearing to the natives (5). But after a while, becoming curious of her outer covering, her clothes, "they sought to pierce the sacred veil of calico," and "so far overstepped the limits of good breeding, as deeply to offend the lady's sense of decorum" (6). Stripped of calico she stands revealed as nothing more than a naked woman, much to the exasperation of the savages, who wondered whether a deception had been practiced upon them. Melville follows this episode with another even more bawdy, more indecorous, and more pointed. An Island Queen appears on a ceremonial visit to a French frigate adorned in the native style, "in a gaudy tissue of scarlet cloth, trimmed with yellow silk, which, descending a little below the knees, exposed to view her bare legs, embellished with spiral tattooing, and somewhat resembling two miniature Trajan's columns" (7). A sight picturesque enough to French sailors, and to American readers, but the picturesque quickly dissolves into a scene of comic distress, when Her Highness, catching sight of a sailor also elaborately tattooed, immediately proceeds to uncover more of his body, delighted at his "bright blue and vermilion pricking" (80). This breach of decorum is embarrassing enough to "the polite Gauls," "but picture their consternation," Melville writes:

when all at once the royal lady, eager to display the hieroglyphics on her own sweet form, bent forward for a moment, and turning sharply round, threw up the skirts of her mantle, and revealed a sight from which the aghast Frenchmen retreated precipitately, and tumbling into their boat, fled the scene of so shocking a catastrophe. $(7)^{13}$

In both cases the subversion of genteel modesty prepares the reader for subsequent events in Tommo's (the narrator) own encounter, deep in the green valley of Typee, with an alien way of life. There, it is true, clothes do not deceive, and the narrator uses that fact along with others to shift the reader's attention toward the terms 'savage' and 'civilized.' A more serious shift occurs as Melville raises questions of perception as well as perspective, of whether physical nakedness is any more trustworthy a guide to character and intention than cloth. Much of the interest in Typee comes from witnessing Melville discovering new themes and searching for methods of presentation; perception, how and finally whether reality can be known from appearances becomes central to the book. A sense of fear, and then terror, begins to encroach upon the hero as he finds himself either deliberately deceived or utterly baffled by his surroundings. The incomprehensible, rather than incidental to the narrative, lies at its heart. "I saw everything," Tommo says about the "secret signs" passing between the natives, "but could comprehend nothing" (227). The remains of a ceremonial monument are "dumb 
stones" to him, the birds in the valley are voiceless, and even Fayaway's eyes are "unfathomable" $(198 ; 108)$. In the end his own naked flesh proves the source of his most deeply felt vulnerabilities: fear of being cannibalized, and fear of being tattooed, inscribed with the tribal hieroglyphics. Melville's method is to strip away assumptions as if so many layers of dress, but in the end nakedness fails to allay anxieties about the appearances of things. In his uses of wardrobe in Redburn, in White-facket, where reliance upon a garment for protection as well as identity proves nearly fatal, and in The Confidence-Man, where elaborate manipulations of sartorial appearance correspond to the book's winding argument, Melville steadily implicates the image of clothes in his intensifying interrogation of relations between appearance and reality.

"[L] ook fixedly on Clothes, or even with armed eyesight, till they become transparent." 14 This motto of Carlyle's Herr Teufelsdröckh holds a clue to Melville's emerging designs upon the fire-side readers he continued to address. His literary problem was to devise methods to persuade readers to recognize that all thoughts and conceptions are garments, that all tools of knowledge, all systems of explanation, are, in a manner of speaking, the cloth men wear, including, Carlyle writes, "your two grand fundamental world-enveloping Appearances, SPACE and TIME. These,"

as spun and woven for us from before Birth itself, to clothe our celestial ME for dwelling here, and yet to blind it - lie all-embracing, as the universal canvass, or warp and woof, whereby all minor Illusions, in this Phantasm Existence, weave and paint themselves. In vain, while here on Earth, shall you endeavor to strip them off; you can, at best, but rend them asunder for moments, and look through. (191)

The echo of Carlyle in Ahab's first great speech can hardly be missed:

Hark ye yet again, - the little lower layer. All visible objects, man, are but as pasteboard masks. But in each event - in the living act, the undoubted deed-there, some unknown but still reasoning thing puts forth the mouldings of its features from behind the unreasoning mask. If man will strike, strike through the mask! ${ }^{15}$

Clothes represent the entire fabric of lies which presents itself as reality, including the most all-embracing conceptions. The truth-seeker is aware of the illusion, aware of ultimate inscrutability and the final inadequacy of cloth or its analogue language to grasp and confine it. The term itself, "inscrutable," may be a disguise, as Ahab passionately believes. The momentary rents in the garment Carlyle speaks of have for Melville a lurking fatality. The lesson of Ahab is that authentic nakedness comes at the cost of life. Short of an unrecoverable ultimate truth, appearances are ever-lastingly insincere. 
The insight, strengthened by his reading in Carlyle, had the force of liberation; it marked an exhilarating freedom from illusion. But how could he persuade us, his fire-side readers, of the awakening truth of the clothes philosophy? The notion of the insincerity of appearances may have seemed his age's guilty secret; let into the open it could well become unbearable, a subverting challenge to confidence in the intelligibility of nature and the efficacy of human action shared by utilitarians and transcendentalists alike. Could the mind sustain the double view of nature as at once benign and inscrutable? The philosophical issue also implicated the status of fiction. Nineteenth-century confidence counted on the expectation, or illusion, that, though "made up," fiction (also poetry, widely taken as a kind or branch of fiction) be "true to nature." But if truth includes, necessarily given the kinds of experience "sailors" are likely to undergo, an irreducible element of the incomprehensible, how could authors who would be taken as truth-tellers validate their also necessarily fabricated fictions? In "Hawthorne and His Mosses," where Melville faces his own predicament as a practitioner, as he calls Hawthorne, of "the great Art of Telling the Truth," he writes that "in this world of lies, Truth is forced to fly like a scared white doe in the woodlands; and only by cunning glimpses will she reveal herself." 16 What he needs is a cunning way to assault the reader's comfortable delusions about the facts and the inherent nature of reality, to take the reader to sea, as it were, where, as Ishmael writes in Chapter 23, "The Lee Shore": "Wonderfullest things are ever the unmentionable" (96). In this chapter, which modulates the narrative from shore to open sea, Melville speaks covertly to his reader, as he does throughout his mature work, about the reader's own situation. It will be with him as it is with Bulkington and with "the storm-tossed ship": "The port would fain give succor; the port is pitiful; in the port is safety, comfort, hearthstone, supper, warm blankets, friends, all that's kind to our mortalities" (97)-as clothes indeed are kind. But when the shore is a lee shore, then "the port, the land, is that ship's direst jeopardy; she must fly all hospitality" (97). The truth afforded by the reader's glimpse of Bulkington is that "in landlessness alone resides the highest truth, shoreless, indefinite as God-so, better it is to perish in that howling infinite, than be ingloriously dashed upon the lee, even if that were safety" (97). Small wonder the book defied capacities of readers in 1851.

Melville wants to induce landlessness, to unmoor readers from the safety of convention, of delusion, illusion, and the whole-cloth of necessary lies exposed by the clothes philosophy. He wants readers to experience, like Pierre taking in the terrible ambiguities of Isabel's face, that his "creed of this world" is shaken. Melville reaches for his most effective trope of this condition he knows must be undergone by 
readers and writers alike, the trope of landlessness: "what he [Pierre] had always before considered the solid land of veritable reality, was now being audaciously encroached upon by bannered armies of hooded phantoms, disembarking in his soul, as from flotillas of specter-boats." 17 Sanity lies in fleeing this condition of madness, yet for certain persons of the caliber of Pierre, Bulkington, Melville himself, and his true readers, all efforts at flight are in vain. Especially is flight blocked to the presumed safety of the notion that fiction as something "merely" made-up is not to be taken seriously enough to disturb inner or outer balance. Especially in Moby-Dick and Pierre, Melville constructs the reader's problem in reading as analogous to the characters' problems in coping with the fictions that present themselves in the mode of whales impossibly white and faces impossibly ambiguous. Reader and character mutually explicate each other. I think this is particularly important to understand about Pierre, where writing within sentimental and gothic conventions while simultaneously undercutting them, Melville locates overwhelming ambiguities of existence at the uncertain boundaries of art and life. The reader's problem in Pierre arises from his need, like Pierre's own need, to free himself from the death-like hold of convention-like mother-love, for instance. Pierre's struggles with his book correspond to the reader's struggles with the one which contains him:

For the more and the more that he wrote, and the deeper and the deeper that he dived, Pierre saw the everlasting elusiveness of Truth; the universal lurking insincerity of even the greatest and purest written thoughts. Like knavish cards, the leaves of all great books were covertly packed. He was but packing one set the more. (462)

"What a madness \& anguish it is," Melville wrote after completing White-facket, "that an author can never-under no conceivable circumstances-be at all frank with his readers" (Letters, 96).

This equivocalness derives from Melville's perception of his predicament as a writer. He knew his audience enjoyed thinking of him as the man who lived among cannibals, who wrote a good story even if his veracity was sometimes dubious. It was the same audience that chose to think of Hawthorne as "a man who means no meanings," closing its eyes to the "great power of blackness" in him (Mosses 1, 126). Either through amusement or edification this audience looked for confirmation in its reading hours of the assurance felt almost everywhere in American society in the 1840's and 1850's, that the nature it was then expanding into and transforming, like the whale's carcass, into saleable chunks, parcels convertible to good old cash, was not only solid but hospitable and sublime. From Hawthorne Melville learned the need and the craft of "hoodwinking the world." Hawthorne's work is "directly calculated to deceive-egregiously deceive, the superficial skimmer of 
pages."18 "Here and there," Melville writes about his fellow fictionist, "in some quiet armchair in the noisy town, or some deep nook among the noiseless mountains, he may be appreciated for something of what he is" (Mosses 1, 126). The lesson, then, is to find a way to deceive the superficial skimmer and appeal to the isolated character among the fire-side readers with whom, as he writes in another context, he might find a "certain spontaneous aristocracy of feeling" (Letters, 126). Yet for all his recognition of what it takes to be popular and meaningful together, he failed. Moby-Dick deceives no one about its wickedness, even if its wickedness may seem, and did to early reviewers, nothing more than its eccentricity, its "unnatural" writing, or its irreverence. On a deeper level, however, covertness emerged for Melville as an essential component of art by the very nature of the enterprise. This is the deception called for in any writer who, like Shakespeare, wants to say "the things which we feel to be so terrifically true, that it were all but madness for any good man, in his own proper character, to utter, or even hint of them" (Mosses 1, 126). Call me Ishmael instead, allow me that provisional and problematic guise, so that, within the mask, and further, within Ishmael's mask of Ahab, things can be said that most law-abiding citizens would refuse to hear otherwise, and more, could not be said at all, in the nature of things as they currently exist, except for the mask.

Not only did Melville feel uneasy toward the idea of fiction as a covenant between himself and his reader, but he came to understand the relation between fiction and reality as necessarily equivocal. Readers expect fiction to be true to life, he comments in The Confidence-Man; yet they are upset by inconsistencies, by intrusions of the incomprehensible. How, they wonder, can truth be served by a fantastic lie? The Confidence-Man elaborately dramatizes this question. The masquerade draws attention to itself, exposes itself, but not for the sake of unmasking. Like Carlyle, Melville understood the world outside the costume or beneath the mask to be inscrutable, like the ensuing darkness of the end of the book. Is the masquerade a paradoxical truth-telling?

"In a Symbol," writes Carlyle, "there is concealment and yet revelation" (162). For "must not the Imagination weave Garments, visible Bodies, wherein the else invisible creations and inspirations of our Reason are, like Spirits, revealed, and first become all-powerful" (55-56). Not all masquerades are merely deceitful; some stand forth as all-powerful, creative symbols whereby man comes to learn of his own capacities. Discussing the "original character," who is the selfsame confidence man himself, Melville compares him to a "revolving Drummond light, raying away from itself all round it - everything is lit by it, everything starts up to it (mark how it is with Hamlet), so that, 
in certain minds, there follows upon the adequate conception of such a character, an effect, in its way, akin to that which in Genesis attends upon the beginnings of things" (373-374). For the "certain minds" to whom such an "adequate conception" is possible, inconsistencies which trouble the common reader and are avoided in successfully popular novels, are a mark of truth, an emblem of reality itself. "[T] hat author who draws a character," Melville writes in a chapter coyly titled "Worth the Consideration of Those to Whom it May Prove Worth Considering," "even though to common view incongruous in its parts, as the flying-squirrel, and, at different periods, as much at variance with itself as the butterfly is with the caterpillar from which it changes, may yet, in so doing, be not false but faithful to facts" (104). Inconsistencies in character, multitudinousness of appearances or masks, as well as inconsistencies in the structure of books, are indicators of reality itself, its everlasting insincerity (one might say contingency) to human eyes. If we take the "original character," the confidence man himself, to represent fiction, or the writer in the guise of fictionist, we see that the costumes, the abrupt shifts in style, the calculated deceptions designed to expose the passengers to themselves, comprise the very work of telling the truth. The costumes, like the endless representations of the whale in cetology, are not so much false as, taken each by itself, inadequate. Like Ahab's charts, they are essential, though limited and limiting, to locate alwaysshifting reality. Remember that Ahab himself says "strike through the mask," meaning even if not intending that the mask itself helps locate the whale and reveal ultimate inscrutability. "Clothes," writes Carlyle, "as despicable as we think them, are so unspeakably significant" (55).

There is no question that a whale exists. Melville does not scorn each local and particular purchase upon it, each particular garb in which it is seen, but is able to use them all precisely because each is limited and narrowly focused. The sometimes maddening juxtaposition of perspectives upon the whale is designed to win the reader from his own particular universe, to train him in "the sane madness of vital truth," which is that all universes of meaning are problematic and none will contain the huge, half-submerged and deadly reality of the thing itself (Mosses 1, 126). The chapters on cetology and whaling technology serve to wean the reader from the expectation that the whale can ever be known or captured, or that bookish knowledge of the whale can be verified by experience. The aim of this attack on the reliability of pictures of reality and tools of measurement and fabrication is to prepare the reader to grasp, indeed to experience for himself, the whole range of implication in the central fable: Ahab's quest for vengeance upon a dumb brute. The cetology can be considered a sort of story of the story, a running commentary on Ahab's story, a progressive deepening 
or lowering of the level on which meaning is to be pursued-until we are made to feel ourselves in the water with the whale, groping for his "unspeakable foundations" (116).

To open a rift in confidence, Melville de-stabilizes his narrator's relation to the reader. A good example occurs in Chapter 55, "Of the Monstrous Pictures of Whales." Ishmael describes "those curious imaginary portraits" of whales and announces, "It is time to set the world right in this matter, by proving such pictures of the whale all wrong" (215). The word "proving" is the reader's trap. The examples of wrong pictures are indeed grotesque, far-fetched, fabulous. There are Greek, Egyptian, Hindoo and Christian examples. No religion or mythology has a monopoly upon error and distortion. As he brings his brief exercise in setting the record straight to an end, Ishmael begins to change his tone and qualify the culpability of artists. After all, "The living whale, in his full majesty and significance, is only to be seen at sea in unfathomable waters" (217). And in the chapter's concluding words, the reader is made aware that a radical shift has occurred under him:

For all these reasons, then, any way you look at it, you must needs conclude that the great Leviathan is that one creature in the world which must remain unpainted to the last. True, one portrait may hit the mark much nearer than another, but none can hit with any very considerable degree of exactness. So there is no earthly way of finding out precisely what the whale really looks like. And the only mode in which you can derive even a tolerable idea of his living contour, is by going a whaling yourself; but by so doing, you run no small risk of being eternally stove and sunk by him. Wherefore, it seems to me you had best not be too fastidious in your curiosity touching this Leviathan. (218)

The reader is left wondering how any version of the whale can be blamed as "all wrong," and what indeed Ishmael himself is doing on this putatively suicidal voyage and whether he will survive it - questions designedly planted by Melville to deepen and intensify the reader's engagement in the story of the story. Ishmael's equivocation, his mode of cunning, may explain why and how he does survive as the only voyager escaped to tell the tale.

Compared to Melville, Whitman looks at first as the model of openhandedness and guilessness. He grants his readers absolute equality"What I shall assume you shall assume" $(L G, 28)$ — and seems to breath confidence in every line. He trusts nakedness, distrusts costumes, and claims for himself complete originality. His will not be poems distilled from other poems, will not in fact be a literary performance at all. Where Melville places the very idea of fiction between his reader and the events represented in his text, Whitman seeks to deny his own art. He wants to disperse the traditional aura surrounding literature, to "de-distantiate" 
his poems, in Karl Mannheim's helpful phrase, from the previously sacred category of poetry, in order to return and plant the poetic within everyday experience in everyday places. He would have us take his poems as vernacular in all senses of the word: there is nothing special about them, and they are open to all. The poems themselves abound in a multitude of images of poetry, designed to prohibit the reader from assuming a normal or customary posture toward them. These are not poems but leaves of grass, not a book but a person, a channel, a sheer opening between the speaker and the reader. "The words of my book nothing," he writes; "the drift of it every thing" $(L G, 13)$.

Fluid, flexible, uncontained by any apparent form, they want to touch and be touched:

The real poems, (what we call poems being merely pictures,)

The poems of the privacy of the night, and of men like me,

This poem drooping shy and unseen I always carry, and that all men carry,

(Know once for all, avow'd on purpose, wherever are men like me, are our lusty lurking masculine poems). (LG, 103)

The annihilation of the image of the traditional poem also annihilates the traditional distance between poet and reader; the "I" and the "you" are mutually radicalized into absolute equality. The "I" may seem the speaker, but "It is you talking just as much as myself....I act as the tongue of you" ( $L G 1855,53)$.

What might Melville have made of such tropes, truly quite outrageous at the time? Through the provisional lens of Melville's eyes we are struck by precisely how insistent and fervent the poet is to undertake the dispersal of aura and de-distantiation within the poems themselves. It becomes clear that the denial of the conventional idea of poetry, such as represented by Longfellow and Tennyson, has a crucial role in leading the reader to understand exactly what kind of poetry the poems want to be. Prohibited from taking the verses as finished and complete verbal constructions that qualify as art because they resemble in form and diction similar constructions encountered elsewhere as poetry, the reader wants definite clues to what is then expected. Whitman's several prefaces and the reviews he wrote of his own book testify to his awareness of the scope and difficulty of the problem. But our interest here is the strictly poetic ways he engages his reader, the ways by which his poems create, construct, conjure into being, their own readers. For, by installing the problem of how to read, to "get at" the meaning of his verses within the verses themselves, Whitman requires his reader to reflect upon himself in the act of reading; part of what the poem is about is himself, the "you," struggling with the words. 
Here lies perhaps the most revealing parallel with Melville. For both, the subject or matter of their work includes the specific difficulties of the work itself. There are great differences in how each proceeds, including the decisive fact that, while Whitman is always invitational even when evasive, Melville becomes increasingly forbidding, to the point that The Confidence-Man is much like an act of aggression against the gullible reader. For Melville, the difficulties lie in the gulf across which he addresses the reader, the gulf which is the fiction itself, the masquerades of language. He is like Father Mapple uttering fables in a dimly-lit enclosure from behind an altar whose cryptic design "must symbolize something unseen" (47). By the time of The Confidence-Man, where the passengers are several times likened to inhabitants of a custom house, the enclosure within which Melville imagines his reader is one which resists expansion. It is made of impenetrable walls. Whitman in turn imagines all enclosures as infinitely elastic and fluid, like the throbbing womb at the moment of parturition: "I recline by the sills of the exquisite flexible doors.... and mark the outlet, and mark the relief and escape" ( $L G 1855,54)$.

The image or energy of escape that is characteristic of Whitman's poems might seem to point to an irreducible difference, and in light of his ease in escaping the "terrible doubt of appearances," it surely does. But as an energy within the poems, escape or evasion may in fact deepen resemblance between the two contemporaries. The energy appears most obviously in the movement of the speaker of "Song of Myself" in and out of identities, each of which is a provisional property of his nakedness. After announcing "what I assume you shall assume," his initial presumption is to extricate himself from "houses and rooms" and "go to the bank by the wood and become undisguised and naked" ( $L G 1855,13)$. He assumes nakedness in order to allow himself an escape from all subsequent guises that would fix him in a single role: "My dinner, dress, associates, looks, business, compliments, dues, / [...]They come to me days and nights and go from me again, / But they are not the Me myself" ( $L G 1855,15)$. Robing and disrobing is one of the defining activities of the poem. ${ }^{19}$ Moreover, the figurative sense of robe or costume extends beyond social identity to the meaning of words themselves. "Writing and talk do not prove me, / I carry the plenum of proof and every thing else in my face, / With the hush of my lips I confound the topmost skeptic" (LG 1855, 31). Nakedness in these lines corresponds to silence, a pregnant silence in which, the poet claims, resides the "plenum of proof." He wants, that is, to escape the confinement of verbal meanings as well as of clothes. Throughout "Song of Myself" he undercuts his own words in this way, scorns their importance, and says, in this most elaborate of modern poems, "To elaborate is no avail" $(L G, 31)$. 
The reader, a figure in the poem, cognate or co-born with the speaker, assuming his assumptions, faces a special problem. How can we respond to this denial of language? If meaning is unfixed from words, where is it found? The reader is refused access to a firm meaning and is thrown back upon himself or herself, in a Whitmanian landlessness:

You shall no longer take things at second or third hand....nor look through eyes of the dead....nor feed on the spectres in books,

You shall not look through my eyes either, nor take things from me,

You shall listen to all sides and filter them from yourself. ( $L G 1855,14$ )

Stripped of the convenience of all convention, of books and images, the reader might wonder: then why the poem? "To indicate reality," Whitman replies-but a reality which does not seem to lie within the language of the poem any more than it lies within the costumes of speaker and reader. The poem presents itself to the reader as an enigma. "There is something that comes home to one now and perpetually," Whitman writes in the second poem in the 1855 edition, later titled "A Song for Occupations"; "It is not what is printed or preached or discussed. . . it eludes discussion and print" ( $L G 1855,59)$. Meaning lies somewhere beyond language. In the same poem he suggests that it lies in an activity in relation to, or provoked by, language. "All architecture is what you do to it when you look upon it," as "All music is what awakens from you when you are reminded by the instruments" ( $L G 1855,61)$. The music itself is not in the instrument any more than the architecture is in the carved stone --or the poetry in the words:

There is that in me....I do not know what it is....but $\mathrm{I}$ know it is in me. [....]

I do not know it....it is without name....it is a word unsaid,

It is not in any dictionary or utterance or symbol. ( $L G 1855,55)$

Yet dictionaries and utterances and symbols evoke it, and they evoke it by the very sense they give of their own inadequacy. Whitman wants to say, before the felt experience. Hence the exquisite interrogation of the grass in "Song of Myself," that begins "How could I answer the child? I do not know what it is any more than he," is a series of guesses, each guess a provisional metaphor (the flag of my disposition, the handkerchief of the Lord, a child, the beautiful uncut hair of graves) designed to prove the inadequacy of any single metaphor and to indicate that the experience itself is a "uniform hieroglyphic," uniformly and universally ineffable $(L G, 34)$.

The poem establishes its own necessity to the extent that it constantly calls itself into question as a final version, constantly points to its own inadequacy before sheer unfiltered experience. Anticipating 
William James and John Dewey, Whitman wants his reader to feel the gap between word and meaning as an essential attribute of both language and experience: reality cannot be captured, cannot be known, except nakedly, because it is in and by its nature elusive, a hieroglyphic: "Not words of routine this song of mine, / But abruptly to question, to leap beyond yet nearer bring" ( $L G, 77)$. The activity of leapingbetween the word and its elusive meaning, between the image and what it almost represents, between "This printed and bound book....but the printer and the printing office-boy"-is meant to bring the reader to the brink of the unspeakable ( $L G 1855,47)$. The value of language seems to lie in its inescapable limitation as a mirror of reality. Whitman characteristically wants to hold in tense equilibrium, as opposites necessary to each other, the image and the meaning, the said and the unsaid, the fixed and the fluid, the "I" and the "you." His elaborate punning on the word "leaves" is an example of this tension, containing in part the vital and the waste, grass and feces, something fixed and something fluid, staying and going, and living and dying. Whitman wants to achieve a language in which there is, as Carlyle wrote about symbols, "concealment and yet revelation," a "double significance" brought about "by Silence and by Speech acting together" (162). And this doubleness indicates a complex role for nakedness, which is itself an image, a guise. Like a confidence man, the speaker flows in and out of disguises. "Agonies," he says, "are one of my changes of garments" $(L G, 67)$ - as the metaphors are garments of the grass, as the grass itself is a garment of an elusive reality. And physical nakedness itself is finally the garb of the ultimately elusive quality of individual being or individuality, named by Whitman the Soul. Nakedness prepares the "bare-stript heart" for the Soul's tongue $(L G, 33)$. But the Soul itself eludes final definition; it hovers in interstices, in its own contradictoriness of appearance. Contradictions of appearance are required to create a sense of multitudes contained within, and a corresponding sense of plenitude without. Do not the speaker's changes of garments in "Song of Myself” qualify him as Melville's “original character," who sheds his light on his surroundings and evokes "an effect, in its way, akin to that which in Genesis attends upon the beginnings of things?"

Nakedness becomes Whitman's symbol for a radically democratic version of vestiture. It is the guise, and a guile, that stands simultaneously for guiselessness and all disguises, for guile of the archest sort and for perfect innocence. It prefigures each identity as a guise, as a provisional assumption serving to delineate the underlying form as multitudinous and universal. The naked Me myself has claim on all identities without being captive to any. And as the identity of the "you" undergoes as many changes of garment as that of the "I," each change 
serves to enlarge the reader's sense of unlimited capacity for experience. Whitman encounters his reader in an elaborate verbal contrivance that steadfastly denies itself, turns itself into undecipherable elements of reality, into air, into eddies, into dirt "under your boot-soles." The aim of the poem is to produce in the reader a readiness to recognize that ultimate limitations of language represent ultimate opportunities for new relations of being to being as such.

Roland Barthes remarked that "modernism begins with the search for a Literature which is no longer possible." ${ }^{20}$ When writers can "no longer be understood with reference to a tradition," their "network of words" calls into question "the existence of Literature" (59; 61). Their radical conceptions of a new kind of reading as in a state of nakedness marks an early symptom in the United States of this crisis in reading that gave rise in the early twentieth century to the revolutionary literary experiments of modernism. Separately, yet with striking resemblances, Melville and Whitman each challenged what was understood by "literature"-fiction and poetry-in their day. Their work denies the stable relationships between word and meaning and between reader and writer that lay at the base of self-confident (yet secretly anxious) nineteenth-century literary audiences shaped by writers such as Scott, Cooper, Longfellow and Tennyson. New and obscure, if not also frightening, demands upon readers by Melville and Whitman are evident symptoms of a cultural crisis in the offing. It may be no accident that their challenge appeared as American society stood on the threshold, in the 1850's, of a political and social crisis of near-fatal consequence for the nation, its own interminable crisis. One effect of the Civil War, the rending of the verbal fabric of rhetorical justifications for America itself, is significantly prefigured in their work.

Whitman seemed more confident than Melville that experience ultimately made sense, made sense especially in the ultimate experience of death, the ultimacy of which it was Whitman's high achievement to render in natural experiential terms. He was able to find in "the subtle air, the impalpable, the sense that words and reason hold not," a sufficiency of assurance against "the terrible doubt of appearances" $(L G, 120)$. And he set about to recreate literature in the new image of that sufficiency. Melville's efforts were more de-creative, to dissolve literature into metaphysical components, to make it a subject in its own right. Experience remains inscrutable, but art serves as an access to inscrutability. In his tale, "The Piazza," where Melville contemplates the meaning of literature in relation to a putative reality, the narrator discovers that art, in the figure of the poor, lonesome girl, Marianna, is a fragile dream erected against nothingness. "II, too, know nothing,", the speaker confesses, and realizes at the end that "every night, when the curtain falls, truth comes in with darkness" (PT, 28-29). 
Differences point to common ground. Whitman would very likely assent to Pierre's discovery that "the leaves of all great books are covertly packed," and Melville might have perceived, "beneath the surface of certain matters here," a similar covertness lurking in the sly evasions and cunning refutations of Whitman's poem, "Whoever You Are Holding Me Now in Hand." The poem might serve as each writer's invocation to his reader. "I give you fair warning," the poet speaks; "I am not what you supposed, but far different" ( $L G, 115)$. You con these leaves at peril, he warns: "Even while you should think you had unquestionably caught me, behold! / Already you see I have escaped from you / [.... ] For all is useless without that which you may guess at many times and not hit, that which I hinted at; / Therefore release me and depart on your way" ( $L G, 116-117)$.

\section{Yale University}

\section{NOTES}

1 Robert Buchanan, "Socrates in Camden, with a Look Round." Academy (August 15, 1885), 102-103. See Harold Blodgett, "Whitman and Buchanan," American Literature (May 1930), 131-140.

2 B. V. [James Thomson], "Walt Whitman. VI." National Reformer (August 30, 1874), 135.

3 The Letters of Herman Melville, ed. Merrell R. Davis and William H. Gilman (New Haven: Yale University Press, 1960), 289. Hereafter, Letters.

4 The Writings of Herman Melville: Correspondence, ed. Lynn Horth (Evanston, I1linois: Northwestern University Press, 1993), 741.

5 Walt Whitman, Leaves of Grass (1855), 13. Hereafter, LG 1855. Available on the Walt Whitman Archive (www.whitmanarchive.org).

6 Walt Whitman, Prose Works 1892, ed. Floyd Stovall (New York: New York University Press, 1984), 2:715. Hereafter, $P W$.

7 Perry Miller, The Raven and the Whale (Baltimore: Johns Hopkins University Press, 1997), 3-7 and passim.

8 Walt Whitman, Leaves of Grass, Comprehensive Reader's Edition, ed. Harold W. Blodgett and Sculley Bradley (New York: New York University Press, 1965), 30. Hereafter, $L G$.

9 Herman Melville, The Confidence-Man: His Masquerade (New York: Dix, Edwards \& Co., 1857), 285, 286.

10 Herman Melville, The Piazza Tales (New York: Dix, Edwards \& Co., 1856), 83. Hereafter, $P T$.

11 Herman Melville, Typee (New York: Wiley and Putnam, 1846), ix. 
12 In the May 5, 1847, Brooklyn Daily Eagle review of Omoo, Whitman writes: “Omoo, the new work . . . by Mr. Melville, author of 'Typee,' affords two well printed volumes of the most readable sort of reading. The question whether these stories be authentic or not has, of course, not so much to do with their interest. One can revel in such a richly good natured style, if nothing else. We therefore recommend this 'narrative of adventures in the south seas,' as thorough entertainment - not so light as to be tossed aside for its flippancy, nor so profound as to be tiresome. All books have their office - and this a very side one." (2)

13 When Typee was first published in 1846, this scene is slightly different: "when all at once the royal lady bent eagerly forward to display the hieroglyphics on her own sweet form, and the aghast Frenchmen retreated precipitately, and tumbling into their boat, fled the scene of so shocking a catastrophe" (8).

14 Thomas Carlyle, Sartor Resartus (Berkeley: The University of California Press, 2000), 51.

15 Herman Melville, Moby-Dick (New York: W.W. Norton \& Company, 2002), 140.

16 [Herman Melville], "Hawthorne and His Mosses," The Literary World (August 17, 1850), 125-127 (126). Hereafter, Mosses 1.

17 Herman Melville, Pierre: or The Ambiguities (New York: Harper \& Brothers, 1852), 64.

18 [Herman Melville], "Hawthorne and His Mosses," The Literary World (August 24, 1850), 145-147 (146).

19 Compare to the vivacious, almost Melvillean exuberance of figurative language, in this account of stripping down in the open air, as if a pendent to "I am mad for it to be in contact with me":

An Early Summer Reveille.

Away then to loosen, to unstring the divine bow, so tense, so long. Away, from curtain, carpet, sofa, book - from "society" - from city house, street, and modern improvements and luxuries - away to the primitive winding, aforementioned wooded creek, with its untrimm'd bushes and turfy banks - away from ligatures, tight boots, buttons, and the whole cast-iron civilizee life-from entourage of artificial store, machine, studio, office, parlor-from tailordom and fashion's clothes-from any clothes, perhaps, for the nonce, the summer heats advancing, there in those watery, shaded solitudes. Away, thou soul, (let me pick thee out singly, reader dear, and talk in perfect freedom, negligently, confidentially,) for one day and night at least, returning to the naked source-life of us all - to the breast of the great silent savage all-acceptive Mother. Alas! how many of us are so sodden-how many have wander'd so far away, that return is almost impossible. (PW, 121-122)

20 Roland Barthes, Writing Degree Zero. trans. Annette Lavers and Colin Smith (New York: Hill and Wang, 1968), 38. 